\title{
Tyrosinase:368-376(370D) Peptide
}

National Cancer Institute

\section{Source}

National Cancer Institute. Tyrosinase:368-376(370D) Peptide. NCI Thesaurus. Code C2820.

A synthetic peptide consisting of amino acids 368 through 376 of the melanomaassociated antigen tyrosinase with an amino acid aspartic acid at position 370 to improve immunogenicity. Vaccination with TYROSINASE:368-376(370D) may stimulate the host immune system to mount a cytotoxic $T$ lymphocyte $(C T L)$ response against tumor cells positive for tyrosinase, thereby decreasing tumor growth. 